\title{
SEJARAH LAMPUNG UTARA (PERIODE PEMBANGUNAN MASA ORDE BARU)
}

\author{
Oleh M. Halwi Dahlan \\ Balai Pelestarian Sejarah dan Nilai Tradisional Bandung \\ Jln. Cinambo No. 136 Ujungberung Bandung \\ Email: halwidahlan_daeng@rocketmail.com
}

\begin{abstract}
Abstrak
Perkembangan suatu daerah bisa dikaji dari hasil yang nampak dari proses pembangunan yang telah dan sedang dilaksanakan. Perkembangan tersebut diperoleh dari pemanfaatan potensi-potensi yang ada. Lampung Utara yang secara geopolitik menjadi batas pulau Sumatera di bagian Utara dan secara geografis memiliki potensi alam yang kaya, dapat diolah menjadi sumber pendapatan asli daerah. Secara demografis, penduduk Lampung Utara adalah sumber daya manusia yang signifikan untuk melaksanakan pembangunan serta menjadi kekuatan untuk mewujudkan tujuan jangka panjang tersebut karena kerukunan mereka yang multietnik.
\end{abstract}

Kata Kunci: Sejarah, pembangunan, perkembangan daerah.

\begin{abstract}
Development of an area can be studied from result seems to be from development process which has and is being executed and of course has purpose of long-range towards prosperity of all the area public. The development obtained from exploiting of the potencys. Lampung Utara that is in geopolitics becomes Sumatra island boundary in upstate and geographically has rich nature potency, changeable become source of earnings of area original. Demographically, resident Lampung Utara is human resource which signifikan to execute development and becomes strength to realize purpose of the long-range because reconciliation they which multiethnic.
\end{abstract}

Keywords : History, development, development of area.

\section{A. Pendahuluan}

Pembangunan suatu daerah adalah suatu langkah yang sistematis, bertahap, melalui perencanaan, dan tinjauan masa depan yang akan dituju. Proses tersebut dilakukan dengan cara menyelaraskan antara potensi yang dimiliki, kemauan, dan keseriusan untuk melakukannya. Potensi yang dimaksud adalah tersedianya sumber daya alam dan sumber daya manusia, dua pilar utama sebagai bahan baku untuk melaksanakan pembangunan. Sedangkan kemauan adalah kemampuan mengeluarkan ide-ide, konsep-konsep yang kemudian diramu menjadi suatu program kerja yang teratur serta dengan penentuan target agar kegiatan tersebut memiliki makna dan hasil nyata. Sementara keseriusan adalah langkah kongkret dari pelaksanaan program tersebut yang dilakukan secara bersama- 
sama dengan penuh tanggung jawab di bawah suatu kepemimpinan yang diakui.

Pembahasan dalam tulisan ini dimulai dari kilasan peristiwa terbentuknya Kabupaten Lampung Utara kemudian disambung dengan pelaksanaan pembangunan terencana secara nasional yang dikenal dengan akronim PELITA di masa Orde Baru. Pembahasan khusus pada Pelita V (1989-1994), karena pada pelita inilah pola pembangunan di Indonesia yang berlangsung selama 25 tahun yang lazim disebut Pembangunan Jangka Panjang (PJP) I berakhir (1969-1994). Pada Pelita Kelima inilah dilakukan perbaikan-perbaikan untuk peningkatan pelaksananaan pembangun-an pada PJP berikutnya (rencana 1994-2019). Pada awal PJP I, pola pembangunan dilaksanakan berdasarkan instruksi pemerintah pusat, dimana sebelumnya (pelita I-IV) pola pembangunan infrastruktur Kabupaten Lampung Utara masih berdasarkan sistem sentralistik (sistem dan pendekatan sektoral).

Dalam rangkaian sejarah panjang Kabupaten Lampung Utara, masalah yang cukup krusial adalah bagaimana kondisi Kabupaten Lampung Utara dalam menghadapi perubahan-perubahan tersebut. Apakah kabupaten ini tetap stagnan atau berubah perlahan sesuai kehendak masa yang dijalaninya, atau justru melakukan loncatan jauh ke depan. Indikator yang digunakan untuk mengukur tingkat perkembangan kabupaten ini akan diperoleh melalui daya serap dan pengolahannya sebagai daerah tingkat II.

Namun demikian, prosedur penelitian sejarah mengharuskan adanya pembatasan temporal maupun spasial. Tujuannya adalah agar tidak terjadi pelebaran historiografi sehingga akan menimbulkan kesan bias pada obyek yang diteliti. Maka batasan temporalnya adalah pembangunan yang berlangsung di masa Orde Baru khususnya menjelang berakhirnya program PELITA yang bersamaan dengan bergantinya Orde Baru dengan Reformasi. Untuk ukuran Indonesia, pada kedua masa inilah pembangunan segala bidang berfluktuasi dan bermetafora. Sedangkan batasan spasialnya adalah Kabupaten Lampung Utara yang saat penelitian ini dilaksanakan telah menjadi bagian dari Provinsi Lampung.

Penelitian sejarah daerah ini merupakan salah satu bentuk rekonstruksi terhadap pelaksanaan program pembangunan di Kabupaten Lampung Utara pada kurun waktu tertentu.

Oleh karena itu untuk mencapai sasaran dan tujuan penelitian yang menjawab permasalahan pokok penelitian serta mendapatkan data yang relevan, maka yang digunakan adalah metode pengumpulan data dengan cara mendatangi lokasi yaitu wilayah Kabupaten Lampung Utara, mengumpulkan informasi tertulis maupun lisan, melakukan pencatatan, hingga membuat laporan. Dalam penelitian ini, informasi tertulis yang dibutuhkan adalah literatur yang relevan dengan judul kegiatan dan diperoleh beberapa buah buku seperti yang tertera pada daftar pustaka. Penggunaan data yang tersedia kemudian dipadukan dengan observasi di lapangan untuk mengantisipasi jika terjadi kekurangan data.

Data yang didapat kemudian diolah bersama sesuai dengan metode atau prosedur penelitian yang menjadi acuan kerja. Metode yang dimaksud adalah metode penelitian dan penulisan sejarah seperti yang diuraikan Louis Gottschalk (1985) yang diterjemahkan oleh Nugroho Notosusanto meliputi heuristik, kritik ekstern, kritik intern, dan historiografi. 


\section{B. Hasil dan Bahasan}

\section{Administratif, Geografis, dan Topografis}

Kabupaten Lampung Utara secara administratif berbatasan dengan tiga kabupaten hasil pemekaran dirinya yaitu Kabupaten Way Kanan di sebelah Utara, Kabupaten Tulangbawang di sebelah Timur, dan Kabupaten Lampung Barat di sebelah Barat, serta Kabupaten Lampung Tengah di sebelah Selatan. Kabupaten Lampung Utara dalam hitungan klimatologi berada pada posisi $4.34^{0}$ 4.06 ${ }^{\circ}$ Lintang Selatan dan $104.30^{\circ}$ $105.08^{0}$ Bujur Timur. Sedangkan bentukan permukaan daratannya terbagi dalam 2 unit topografis yaitu perbukitan dan pegunungan dengan ketinggian 450$1500 \mathrm{~m}$ dpl di sepanjang Bukit Barisan dengan hiasan puncak Bukit Barisan dan Bukit Pesagi. Unit berikutnya adalah River Basin atau hamparan sungai. Terdapat 15 sungai yang mengalir di wilayah Lampung Utara dan menjadi sumber pengairan sawah-sawah petani. Sungai terpanjang adalah Way Rarem 42 km terpendek Way Sungko Hilir $25 \mathrm{~km}$. Rata-rata iklim di wilayah ini mencapai $30^{\circ} \mathrm{C}$ dengan pergantian musim antara hujan dan kemarau sebagaimana lazimnya daerah tropis.

\section{Pemerintahan}

Keberadaan sumber daya alam (SDA) dan sumber daya manusia (SDM) yang menjadi potensi pembangunan daerah turut diperhitungkan, dan dengan motto Gertak Saburai Sikep yang merupakan penyederhanaan dari Gerbang Sakai Sambaian Lampura Sikep, pemerintah Kabupaten Lampung Utara menggerakkan masyarakat secara gotong royong untuk pembangunan pedesaan. Harapan yang ingin dicapai dari motto ini adalah agar pelaksanaan pembangunan di pedesaan dan perkotaan di Lampung Utara dapat berdaya guna dan berhasil guna, menggerakkan partisipas masyarakat secara efektif, sejak dari perencanaan hingga pertanggungjawaban hasil-hasil pembangunan menuju kesejahteraan bersama.

\section{Demografi}

Berubahnya luas wilayah akibat pemekaran berpengaruh pada jumlah penduduk Kabupaten Lampung Utara dan praktis mempengaruhi jumlah kepadatan penduduknya. Sebelum terbentuknya Kabupaten Lampung Barat pada tahun 1991, jumlah penduduk Lampung Utara sebanyak 1.655.018 jiwa dengan kepadatan 84 penduduk per $\mathrm{Km}^{2}$ (kondisi tahun 1990 berdasarkan registrasi akhir tahun Kantor Statistik Lampung Utara). Tahun 1997 ketika terjadi pemekaran kedua dengan terbentuknya Kabupaten Tulangbawang, jumlah penduduk 957.765 jiwa dengan kepadatan 144,08 penduduk per $\mathrm{Km}^{2}$ (kondisi tahun 1998). Untuk melihat gerak jumlah penduduk perhatikan tabel berikut:

\section{Tabel 1}

Jumlah dan Kepadatan Penduduk dan Luas Wilayah Kabupaten Lampung Utara Kondisi tahun 1974, 1980, 1990, 1998 , 2000, dan 2006.

\begin{tabular}{|c|c|c|c|}
\hline Tahun & $\begin{array}{c}\text { Jumlah } \\
\text { Penduduk } \\
\text { (Jiwa) }\end{array}$ & $\begin{array}{c}\text { Kepadatan } \\
\text { Penduduk } \\
\text { Per Km }\end{array}$ & $\begin{array}{c}\text { Luas } \\
\text { Wilayah } \\
\left(\mathrm{Km}^{2}\right)\end{array}$ \\
\hline 1974 & 570.117 & 33 & $17.340,00$ \\
\hline 1980 & 882.368 & 46 & $19.368,50$ \\
\hline 1990 & 1.655 .018 & 84 & $19.723,71$ \\
\hline 1998 & 957.765 & 144,08 & $6.647,26$ \\
\hline
\end{tabular}

Sumber: Data diolah dari Lampung Utara Dalam Angka 1974, 1980, 1990-1991, 1998.

Data pada tabel di atas menunjukkan betapa berpengaruhnya luas wilayah kepada jumlah penduduk. Puncak pertumbuhan penduduk Kabupaten 
Lampung Selatan terjadi pada tahun 1990 meningkat 772.650 jiwa dari sepuluh tahun sebelumnya, padahal selisih luas wilayah hanya sekitar $355,21 \mathrm{~km}^{2}$. Kondisi normal terlihat pada kurun waktu tahun 2000-2006. Jumlah penduduk merambat naik. Pertumbuhan ini menandakan kehidupan di Lampung Utara pada kurun waktu tersebut cukup baik karena tidak terdapat lonjakan jumlah penduduk maupun penurunan drastis, sedangkan luas wilayah tetap tidak berubah. Ini dimungkinkan karena suksesnya program Keluarga Berencana dan pola hidup sehat yang diterapkan pemerintah dan masyarakat Kabupaten Lampung Utara.

\section{Sosial Budaya}

Penduduk sebagai kekuatan SDM pembangun dan objek pembangunan akan berpotensi baik jika ditunjang dengan pendidikan yang memadai. Oleh karena itu, pemerintah daerah bersama pihak swasta terus berupaya meningkatkan jumlah sarana pendidikan dalam berbagai tingkatan, termasuk pendidikan non-formal atau pelatihan dan kursuskursus.

Dari segi kesehatan, keberadaan Rumah Sakit Umum Daerah Ryacudu serta 189 Puskesmas yang tersebar di 23 kecamatan, menjadi sarana pokok terjaminnya kesehatan masyarakat. Kemudian guna menekan jumlah penduduk, keberadaan 87 klinik KB (terbanyak di Kecamatan Kotabumi Selatan yaitu 13 klinik) sangat membantu pelayanan pemasangan alat kontrasepsi. Tercatat sebanyak 22.346 menggunakan alat kontrasepi baik IUD, MOP, MOW, dan IMP dari 110.943 Pasangan Usia Subur (PUS).

Dalam bidang kebudayaan, Berdasarkan motto program pembangunan yang digunakan oleh pemerintah daerah dengan memperhatikan ciri khas dan kebiasaan masyarakatnya, maka hidup bersama dan bergotong royong menyelesaikan masalah melalui tindakan yang efektif dan efisien, menjadi identitas masyarakat Lampung Utara.

\section{Profil Lampung Utara}

Toponimi daerah di Indonesia biasanya berkaitan dengan legenda atau cerita rakyat yang berkembang di tengahtengah masyarakatnya. Legenda ini adalah salah satu kekayaan nusantara dari segi oral tradisional yang di dalamnya terkandung nilai yang sangat tinggi terutama untuk pengajaran budi pekerti dan pembangkit semangat berkarya di samping penanaman rasa kekaguman (cinta asal-usul). Hanya saja kekaguman tersebut jangan sampai melahirkan etnosentris yang sempit karena tidak akan dapat membuat daerah tersebut berkembang melainkan terus terpuruk dan terkungkung.

Membicarakan Lampung Utara, tidak dapat dipisahkan begitu saja dengan proses terjadinya Provinsi Lampung. Karena sejarah keduanya saling berkaitan erat, karena dibentuk pada masa yang sama dan Lampura adalah bagian dari Provinsi ini. Namun demikian Lampura tidak memiliki legenda atau cerita rakyat yang sifatnya oral tradisional, sementara Lampung memiliki beragam cerita tentang terbentuknya "lampung" itu sendiri. Adapun Lampura yang merupakan akronim dari Lampung Utara yang tidak memiliki cerita rakyat tentang asal muasalnya, disebabkan gabungan kedua kata yang digunakan sebagai nama daerah (lampung dan utara) tersebut lebih bersifat nasional dan berdasar pada letak secara geografis di sebelah utara Propinsi Lampung. 


\section{Sejarah Pemerintahan Kabupaten Lampung Utara}

\section{a. Pemerintahan Hindia Belanda}

Ketika perang Diponegoro (18251830) masih berkecamuk, perluasan hagemoni jajahan ke wilayah Sumatera bagian selatan tetap dilakukan oleh pemerintah Hindia Belanda. Pasukan Kapten J.A. Du Bois memperluas kekuasaan di daerah Lampung.

Setelah menaklukkan Tulangbawang, Abung, dan Seputih, Du Bois kemudian mengusulkan agar Lampung menjadi karesidenan di bawah pemerintahan Hindia Belanda. Pemerintah Hindia Belanda kemudian menetapkan Lampung sebagai salah satu keresidenan berdasarkan Surat Keputusan Pemerintah Hindia Belanda tanggal 25 September 1829 sekaligus menetapkan Terbanggi sebagai ibukota karesidenan dan J.A. Du Bois sebagai kepala pemerintahan sipil dan militer di Lampung ${ }^{1}$. Bentuk pemerintahan karesidenan Lampung berlangsung hingga tahun 1964 .

Pada masa itu Lampung Utara belum terbentuk, tetapi peranan Tulangbawang, Abung, dan Seputih yang menjadi sasaran penyerangan $\mathrm{Du}$ Bois tampaknya cukup signifikan. Jika tidak, mengapa Du Bois membatalkan penyerangannya terhadap Palembang dan memilih Tulangbawang untuk diduduki.

Tulangbawang termasuk kota kuno yang telah eksis sejak masa kerajaan Sriwijaya $^{2}$. Ketiga daerah tersebut kemudian menjadi bagian dari wilayah Kabupaten Lampung Utara.

\section{b. Pemerintahan Jepang}

Pasca penyerangan atas Pearl Harbour di Pasifik pada Desember 1941, Hindia Belanda segera mendapat giliran.

\footnotetext{
${ }^{1}$ Prof. H. Hilman Hadikusuma, SH., 1990:80.

${ }^{2}$ Drs. R. Soekmono, 1987:37.
}

Tanda-tanda tersebut sudah ada sebab pada tanggal 26 Desember 1941 pangkalan angkatan laut di Danau Tondano Sulawesi Utara diserang pesawat-pesawat tempur Jepang hingga akhirnya dikuasai pada tanggal 10 Januari $1942^{3}$. Akhirnya memasuki tahun baru 1942 Hindia Belanda mengalami masa perubahan dari kolonialisme menjadi imperialisme.

Belanda yang selama 323 tahun menjadikan Nusantara sebagai koloni kerajaannya ternyata tidak memiliki kekuatan perang yang signifikan. Bahkan pada tahun 1941 berbagai konvensi telah dilaksanakan di Eropa yang sebagian hasilnya adalah membantu Belanda jika sewaktu-waktu Jepang melakukan serangan. Kenyataannya pergerakan militer Jepang dengan sangat mudah memasuki Hindia Belanda setelah armada pertahanan lautnya ditenggelamkan satu persatu oleh Jepang. Bulan Maret 1942 adalah bulan penting sebagai masa akhir kekuasaan kolonialis Belanda sekaligus sebagai masa awal kekuasaan militeris Jepang di Nusantara.

Tanggal 1 Maret 1942 armada perang Jepang telah berada di pantai Jawa di bawah pimpinan Jenderal Imamura Hitsoji. Tujuh hari kemudian tepatnya tanggal 8 Maret 1942 Jenderal Ter Poorten sebagai Panglima Tetinggi Angkatan Bersenjata Hindia Belanda ${ }^{4}$ menyatakan menyerah atas nama seluruh Hindia Belanda di hadapan Jenderal

\footnotetext{
3 Onghokham. Runtuhnya Hindia Belanda. Cet Kedua. Jakarta: Gramedia, 1989 : 224-232.

${ }^{4}$ Tanggal 5 Maret 1942 Gubernur Jenderal Tjarda van Stachouwer (1936-1942) menerima telegram dari Ratu Wilhelmina tentang keputusan ratu (Koninklijk Besluit) di pengungsiannya di London -karena negeri Belanda diduduki oleh Jermanbahwa pimpinan perang yang seharusnya ditangan gubernur jenderal diserahkan kepada Jenderal Ter Poorten. Ibid : 262.
} 
Imamura disaksikan oleh Gubernur Jenderal Tjarda, beberapa perwira militer Belanda maupun Jepang serta wartawan dan fotografer dari Jepang. Peristiwa ini berlangsung di Kalijati-Subang.

Setelah takluknya Hindia Belanda kepada Jepang, maka dikeluarkanlah Undang-undang Seirei (Osamu Seirei) tentang segala sesuatu yang menyangkut pemerintahan militer Jepang di Indonesia. Kedudukan ketiga panglima perang ${ }^{5}$ demikian menentukan seperti diatur dalam pasal 2 Osamu Seirei No.1/1942 yaitu:

"Pembesar Balatentara Dai Nippon memegang kekuasaan pemerintahan militer yang tertinggi dan juga segala kekuasaan yang dahulu ada di tangan Gubernur Jenderal"6

Pembagian daerah militer ini membawa konsekuensi kepada struktur pemerintahan Binnenlads Bestuur yang ditinggalkan Gubernur Jenderal Tjarda. Sebab dengan adanya pembagian tersebut, maka jalur dekonsentrasi yang terdiri dari Nederlands Binnenlands Bestuur (NBB) dan Inlands Binnenlands Bestuur (IBB) mengalami perubahan. NBB yang dijabat oleh orang Belanda dihapuskan sama sekali, sedangkan IBB sebagai jalur pemerintahan pribumi tetap dipertahankan.

Dipertahankannya IBB ini oleh pemerintah militer Jepang karena pada masa awal pendudukan konsentrasi

5 Jepang membagi 3 daerah pendudukannya sebagai wilayah teritorial militer yang menempatkan para panglimanya sebagai pemegang kekuasaan atas wilayah-wilayah tersebut, yaitu; Untuk Sumatera dikuasai oleh Riku-gun (dari unsur Angkatan Darat ke 16), Jawa dan Madura oleh Riku-gun ke 25, dan wilayah bekas Hindia Belanda lainnya terutama daerah Timur dikuasai oleh Kai-gun (Angkatan Laut) Jepang. Drs. Bayu Surianingrat. Op.Cit.: 69

${ }^{6}$ Ibid :70. masih pada pertahanan setelah terjadi perebutan kekuasaan, ditambah adanya keinginan mencari simpatik dari rakyat Indonesia agar dapat membantu tercapainya kemenangan perang bagi Jepang.

Dihilangkannya NBB yang merupakan korps pemerintahan Belanda menyebabkan jabatan-jabatan seperti gubernur, residen, asisten residen, kontrolir, adspiran kontrolir yang semuanya dijabat oleh orang Belanda juga ditiadakan. Penghapusan ini wajar dilakukan pemerintah militer Jepang, karena selain Belanda adalah musuhnya, klasifikasi atau pemisahan kekuasaan antara orang Belanda dengan pejabat pribumi dalam pemerintahan ini sebenarnya sangat dibenci oleh para penguasa pribumi dan orang-orang pergerakan. Sebab setinggi-tingginya pejabat pribumi, mereka tetap harus tunduk dan patuh kepada pejabat dari Bangsa Belanda. Jepang yang melihat kondisi seperti ini memanfaatkannya dengan menggalang seluruh kekuatan politik lokal untuk tetap memegang pengaruh sementara itu bentuk pemerintahan yang menempatkan orang-orang Belanda di tempat teratas dihapuskan. Akan tetapi, meski perubahan tersebut telah mengangkat hegemoni penguasa pribumi, namun penjajah tetaplah penjajah dan rakyat pribumi (apapun jabatan dan statusnya) tetaplah orang terjajah. Mereka tetap harus tunduk dan patuh kepada ketentuan pemerintahan militer Jepang.

Pemerintahan militer Jepang berdasarkan Osamu Seirei No. 1/1942 memberlakukan struktur pemerintahan dengan menempatkan para panglima militer (Gunsereikan), pimpinan militer (Seiko Shikikan), dan kepala pemerintahan militer (Gunseikan) sebagai pucuk struktur birokrasinya. Kemudian di bawahnya terdapat jabatan 
Syuucokan (sama dengan posisi residen di masa Hindia Belanda) semuanya dijabat oleh orang Jepang.

Seperti telah disebutkan di atas bahwa korps pemerintahan pribumi atau IBB tetap dipertahankan maka jabatan seperti bupati, walikota, wedana, camat, dan desa tidak berubah kecuali nama jabatan tersebut disesuaikan dengan bahasa Jepang. Sehingga untuk jabatan bupati disebut $\mathrm{Ken}$, walikota disebut $\mathrm{Si}$, wedana disebut Gun, camat disebut Son, dan desa disebut $K u$. Susunan jabatan pemerintahan di daerah ini tertuang dalam pasal 1 Osamu Seirei No. 27/1942.

Adapun penyebutan nama jabatan tersebut berbeda antara pejabat Jepang dengan pribumi. Jabatan residen atau Syuu pejabatnya disebut Syuucokan. Kata co-kan bermakna orang yang lebih kuasa atau lebih terhormat dapada para pejabat pribumi. Sedangkan pada jabatan Ken, Si, Gun, Son, dan Ku cukup diberi tambahan "co" yang berarti kepala, sehingga sebutan bagi bupati adalah Kenco artinya kepala kabupaten, Si-co sama dengan kepala kotamadya, Gun-co tidak lain adalah kepala kewedanaan, Son-co bermakna kepala kecamatan, dan $\mathrm{Ku}$-co berarti kepala desa. Semua ini adalah jabatan formal sekaligus lambang status sosial dalam lingkungan birokrasi pemerintahan Jepang.

Perubahan nama ini menjadi bukti bahwa Jepang tidak melakukan perubahan pada struktur pemerintahan pribumi yang telah terbentuk ketika pemerintah Hindia Belanda bekuasa. Perubahan dilakukan hanya berupa penyesuaian sebutan sesuai bahasa pemerintahan negeri Jepang. Dalam rangka menarik simpati rakyat Indonesia maka para pemimpin dari kalangan birokrat pribumi termasuk kaum pergerakan dirangkul sepanjang tidak bertentangan dengan aturan militer Jepang sebaliknya bagi yang melakukan pelanggaran, Jepang sangat tegas memberlakukan hukuman berat. Hal ini bukan sesuatu yang aneh karena suasana waktu itu dalam keadaan darurat militer.

\section{c. Orde Lama}

Diberlakukannya Undang-undang No. 1 tahun 1945 menjadikan posisi Lampung Utara sebagai salah satu kabupaten dalam wilayah Karesidenan Lampung. Kabupaten ini terbagi dalam beberapa kawedanan, kecamatan, dan marga. Kemudian pada tanggal 3 Desember 1952 diberlakukan peraturan Residen Lampung No. 153/1952 tentang penghapusan pemerintahan marga kemudian diganti dengan pemerintahan negeri. Sistem ini pun tidak berlangsung lama, karena setelah keluarnya Undangundang No. 18 tahun 1965 status negeri dan kewedanan akhirnya dihapuskan.

Sistem pemerintahan marga di bawah kecamatan yang diberlakukan tersebut tampaknya dirujuk pada pengelompokan marga-marga yang ada serta luas tanah ulayatnya. Namun karena jumlah marga terlalu banyak, maka dilakukan penyeimbangan sehingga dibentuk sisten negeri yang terdiri dari beberapa marga. Akan tetapi ternyata sistem ini menimbulkan keruwetan dalam hal otonomisasi kenegerian, sebab ternyata setelah terjadi pemekaran kecamatan, dampaknya ada beberapa wilayah negeri yang memiliki induk ganda atau berada didua kecamatan berbeda. Adapun sistem kewedanan dihapuskan lebih ditujukan pada efisiensi dan efektifitas kinerja dengan

\footnotetext{
7 Sistem marga dalam pemerintahan lokal di Lampung adalah bentuk pemerintahan tradisional yang telah berlangsung demikian lama dan sangat demokratis, karena pemimpin yang dipilih adalah orang yang dianggap dapat membawa dan menggunakan adat istiadat.
} 
pertimbangan memperpendek jarak atau jenjang pemerintahan.

Setelah dihapuskannya sistem pemerintahan negeri di bawah kecamatan, sistem pemerintahan menjadi desa yang menggunakan batas-batas alam sebagai batas wilayah. Namun kekisruhan antarbatas wilayah di Indonesia bukan persoalan baru, bahkan sampai masa reformasi persoalan batas wilayah (desa, kecamatan, kabupaten, bahkan sampai negara misalnya Pulau Sipadan dan Legitan antara Indonesia dengan Malaysia) masih menjadi masalah cukup krusial.

Sejak 25 September 1829 status Lampung menjadi karesidenan, kemudian sejak dikeluarkannya UU No. 4 Darurat tahun 1965 juncto UU No. 28 tahun 1959 tentang Pembentukan Daerah Otonom Kabupaten - Kabupaten dalam Lingkungan Sumatera Selatan, terbentuklah Kabupaten Lampung Utara dibawah Propinsi Sumatera Selatan, maka sistem pemerintahan kawedanan dan marga yang kemudian menjadi negeri berada di bawah Provinsi Sumatera Selatan. Ketika Undang-undang RI No. 14 tanggal 18 Maret 1964 tentang pengangkatan status Karesidenan Lampung menjadi Daerah Tingkat I atau menjadi provinsi otonom, maka sistem pemerintahan kawedanan dan negeri dalam wilayah Kabupaten Lampung Utara masuk dalam wilayah provinsi baru ini. Selain Lampung Utara, 3 daerah lainnya yaitu Kabupaten Lampung Tengah, Kabupaten Lampung Selatan, dan Kodya Tanjungkarang juga menjadi bagian dari Provinsi Lampung.

\section{d. Orde Baru}

Masa Orde Baru merupakan puncak perkembangan Lampung Utara apabila dirunut dalam kurun waktu 169 tahun (1829-1998) sejak masa pembentukan Karesidenan Lampung hingga jatuhnya Orde Baru. Dalam masa
Orde Baru terjadi pemekaran wilayah beberapa kali yang memberi dampak pada luas wilayah, jumlah penduduk, dan potensi alam yang semakin berkurang. Walaupun dampak lainnya meningkat seperti jumlah pegawai pemerintah daerah bertambah, fungsi kontrol terhadap SDA maupun SDM semakin terfokus, pembangunan lebih merata berdasarkan urgensinya, dan sebagainya.

Data statistik Kabupaten Lampung Utara pertahun 1974, jumlah kecamatan 24 buah dengan luas daerah 17.394,00 $\mathrm{km}^{2}$. Luas wilayah tersebut mengalami peningkatan pada tahun 1985 yakni dari 17.349,00 $\mathrm{Km}^{2}$ menjadi $19.368,50 \mathrm{Km}^{2}$. Penambahan cukup signifikan ini disebabkan beberapa daerah bertambah luas, di lain pihak daerah lainnya menyusut. Keduapuluh empat kecamatan tersebut seperti tertera pada tabel berikut:

\section{Tabel 2}

Kecamatan dan Perbandingan Luas Daerah Kabupaten Lampung Utara Tahun 1974 dan Tahun 1985

\begin{tabular}{|c|c|c|c|c|}
\hline \multirow[b]{2}{*}{ No } & \multirow[b]{2}{*}{ Kecamatan } & \multicolumn{2}{|c|}{ Luas Daerah $\left(\mathrm{km}^{2}\right)$} & \multirow[b]{2}{*}{$\begin{array}{l}\text { Ket. } \\
\left(\mathrm{km}^{2}\right)\end{array}$} \\
\hline & & $\begin{array}{c}\text { Tahun } \\
1974\end{array}$ & \begin{tabular}{|l|} 
Tahun \\
1985
\end{tabular} & \\
\hline | & Kotabumi & 300,59 & 338,52 & N 37,93 \\
\hline 2 & Abung Barat & 366,76 & 390,91 & N 24,15 \\
\hline 3 & Abung Timur & 303,09 & 214,98 & T88, II \\
\hline 4 & Abung Selatan & 306,98 & 429,63 & N122,65 \\
\hline 5 & Tanjungraja & 295,81 & 331,70 & $\mathrm{~N} 35,89$ \\
\hline 6 & Bukit Kemuning & 393,10 & 248,04 & T145, प्G \\
\hline 7 & Baradatu & 304,66 & 267,25 & T37.41 \\
\hline & Banjit*** & 358,72 & 331,60 & T 27,12 \\
\hline
\end{tabular}

\begin{tabular}{|c|c|c|c|c|}
\hline \multirow[b]{2}{*}{ No } & \multirow[b]{2}{*}{ Kecamatan } & \multicolumn{2}{|c|}{ Luas Daerah $\left(\mathrm{km}^{2}\right)$} & \multirow[b]{2}{*}{$\begin{array}{l}\text { Ket. } \\
\left(\mathrm{km}^{2}\right)\end{array}$} \\
\hline & & $\begin{array}{l}\text { Tahun } \\
1974\end{array}$ & $\begin{array}{l}\text { Tahun } \\
1985\end{array}$ & \\
\hline 9 & Kasuy*** & 310,34 & 357,38 & N 47,04 \\
\hline I0 & $\begin{array}{l}\text { Blambangan } \\
\text { Umpu }^{* * *}\end{array}$ & $1.450,42$ & 1.302,29 & T148,13 \\
\hline II & Bahuga*** & 394,08 & 372,00 & T 22,08 \\
\hline
\end{tabular}




\begin{tabular}{|c|c|c|c|c|}
\hline & Pakuon Ratu**** & $1.157,81$ & $\mid 1.291,11$ & N 133,30 \\
\hline 13 & Sungkai Utara & 311,79 & 331,82 & N 20,03 \\
\hline 14 & Sungkai Selatan & 395,20 & 440,03 & N 44,83 \\
\hline 15 & $\begin{array}{|lr|}\text { Tulang } & \text { Bawang } \\
\text { Udik** } & \\
\end{array}$ & 283,86 & 337,47 & N53,61 \\
\hline I6 & $\begin{array}{|ll|}\text { Tulang } & \text { Bawang } \\
\text { Tengah** } & \\
\end{array}$ & $1.129,98$ & 784,28 & T 345,70 \\
\hline 17 & Menggala** & $2.398,84$ & $2.340,12$ & T58,72 \\
\hline 18 & Mesuji Lampung** & 2.610,04 & $4.308,97$ & N I.698, 83 \\
\hline 19 & Sumber لaya* & 387,35 & 541,94 & N 154,59 \\
\hline 20 & Balik Bukit* & 487,57 & 363,46 & T 124,II \\
\hline 21 & Pesisir Utara* & 551,60 & 672,39 & $N$ 120,79 \\
\hline 22 & Pesisir Tengah* & 169,30 & 185,03 & $\mathrm{~N} 15,73$ \\
\hline 23 & Pesisir Selatan* & $1.477,50$ & $2.100,33$ & N 622,83 \\
\hline 24 & Belalau* & $1.203,61$ & $1.087,25$ & TIIG,36 \\
\hline & Jumlah & $17.349,00$ & $19.368,50$ & N 2.019,50 \\
\hline
\end{tabular}

Sumber: Lampung Utara Dalam Angka 1974 dan 1985-1986.

Keterangan:

$\mathrm{T}=$ Turun $\mathrm{N}=$ Naik

* Kecamatan ini pindah ke Kabupaten Lampung Barat tahun 1991

** Kecamatan ini pindah ke Kabupaten Tulangbawang tahun 1997

*** Kecamatan ini pindah ke Kabupaten Way Kanan tahun 1999

Dari data di atas, kecamatan tertinggi peningkatan luas wilayahnya adalah Kecamatan Mesuji Lampung yang naik $1.698,93 \mathrm{~km}^{2}$. Sedangkan kecamatan yang turun drastis adalah Kecamatan Tulang Bawang Tengah menyusut 345,70 $\mathrm{km}^{2}$. Perubahan luas wilayah ini tampaknya disebabkan oleh kendala teknis ketika penghitungan berlangsung. Walaupun terdapat pertanyaan besar, jika memang kendala penghitungan yang menjadi penyebab, mengapa begitu besar selisih jumlah tersebut. Karena sangat unik nama-nama kecamatan tidak berubah, tetapi luas wilayah mencengangkan.

Dalam kurun waktu 1966-1998, Kabupaten Lampung Utara mengalami dua kali pemekaran wilayah yaitu terbentuknya Kabupaten Lampung Barat berdasarkan UU No. 6 Tahun 1991 yang menyebabkan 6 kecamatannya ikut berpindah. Keenam kecamatan tersebut adalah: Sumber Jaya, Balik Bukit, Belalau, Pesisir Tengah, Pesisir Selatan, dan Pesisir Utara. Pemekaran kedua terjadi berdasarkan UU No. 2 tahun 1997 dimana empat kecamatannya berpindah induk ke kabupaten baru yaitu Kabupaten Tulangbawang. Keempat kecamatan tersebut adalah: Kecamatan Menggala, Tulangbawang Tengah, Tulangbawang Udik, dan Mesuji.

\section{e. Masa Pembangunan}

Pembangunan di Lampung Utara yang menggunakan motto Gertak Saburai Lampura Sikep adalah suatu sikap mental masyarakat dalam membangun daerahnya. Setiap kata dalam motto tersebut dimaknai oleh warga Lampung Utara sebagai jiwa semangat dan etos kerja serta cerminan orang Lampung Utara Sikep.

Dalam masa Orde Baru, program pembangunan dilakukan secara nasional dan sentralistik melalui suatu program berjangka pendek dan panjang. Pembangunan jangka pendek diberi nama Pembangunan Lima Tahun (Pelita), sedangkan program pembangunan jangka panjang disebut Rencana Pembangunan Lima Tahun (Repelita). Sampai dengan kejatuhan rezim ini tercatat telah dilampaui enam Pelita dan satu Repelita.

\section{f. Pembangunan di Lampung Utara}

Sebagaimana daerah lainnya di Indonesia, pembangunan di Lampung Utara dilaksanakan berdasarkan sektorsektor yang disesuaikan dengan potensipotensi yang dimiliki. Sektor-sektor perekonomian yang dibangun setiap daerah mengacu pada 3 sektor utama yaitu sektor primer, sekunder, dan tersier. Ketiga sektor utama ini dirujuk dari 
System of National Accounts (SNA) yang diterbitkan oleh United Nation. Setiap daerah kemudian menerjemahkan tiga sektor utama tersebut berdasarkan potensi yang dimiliki.

Ketiga sektor utama yang dapat dikembangkan di Lampung Utara berdasarkan potensi yang ada (kondisi tahun 1987-1992) adalah: Sektor Primer meliputi; pertanian, pertambangan, dan penggalian; Sektor Sekunder meliputi; industri pengolahan, listrik dan air minum, bangunan dan konstruksi; Sektor Tersier meliputi; perdagangan, restoran dan hotel, pengangkutan, komunikasi, bank dan lembaga keuangan, sewa rumah, pemerintahan, pertahanan, dan sektor jasa. Setiap sektor memiliki sub sektor yaitu:

- Pertanian terdiri dari; tanaman bahan makanan, tanaman perkebunan, kehutanan, peternakan, dan perikanan.

- Pertambangan dan penggalian

- Industri pengolahan meliputi; industri kecil dan rumah tangga, industri besar dan sedang.

- Listrik, gas, dan air minum.

- Bangunan dan konstruksi

- Perdagangan, restoran, dan hotel terdiri dari; perdagangan eceran dan besar, rumah makan, perhotelan.

- Pengangkutan; pengangkutan darat, udara, dan laut.

- Komunikasi

- Bank, asuransi, lembaga keuangan lainnya.

- Sewa rumah.

- Pemerintahan

- Pertahanan

- Jasa-jasa terdiri dari; jasa sosial dan kemasyarakatan, jasa hiburan dan kebudayaan, jasa perseorangan dan rumah tangga, dan jasa perusahaan. ${ }^{8}$

\footnotetext{
${ }^{8}$ Sumber: Departemen Pekerjaan Umum Republik Indonesia.
}

Sektor-sektor pembangunan ini terus dilanjutkan pada tahun-tahun berikutnya. Namun demikian juga ada beberapa perubahan yang sebenarnya adalah penyesuaian sebagai akibat adanya sektor yang mengalami stagnasi atau mencapai titik jenuh. Perubahan yang dimaksudkan adalah sektor-sektor yang memiliki potensi untuk dikembangkan, terus dipacu sehingga dapat menjadi sektor andalan, menyusul sektor-sektor besar yang cenderung memiliki hasil yang berfluktuasi. Oleh karena itu pada periode 1999-2003 sektor yang dikembangkan meliputi:

- Pertanian; tanaman bahan makanan, tanaman perkebunan, peternakan dan hasil-hasilnya, kehutanan, dan perikanan. Kegiatan sektor ini mencakup segala pengusahaan dan pemanfaatan benda atau barang hidup yang diperoleh dari sumber daya alam Lampung Utara. Aktifitas disektor ini meliputi usaha bercocok tanam, pemeliharaan ternak, penangkapan ikan, dan pengambilan hasil laut.

- Pertambangan dan penggalian; minyak dan gas bumi, pertambangan tanpa migas, dan penggalian. Cakupan aktifitas di sektor ini meliputi usaha penggalian, pengeboran, pencucian, pengambilan, dan pemanfaatan segala macam barang tambang, mineral dan barang galian yang terdapat di dalam tanah baik dalam bentuk benda padat, cair, dan gas.

- Industri pengolahan: Industri migas; pengolahan minyak bumi dan gas alam cair; Industri tanpa migas. Sektor ini memiliki aktifitas pengolahan bahan organik dan anorganik menjadi produk baru yang bermutu tinggi dan diproses melalui 
keterampilan tangan, kimiawi, ataupun dengan mesin.

- Listrik dan air bersih. Dalam PDRB (Produk Domestik Regional Bruto) nasional selain kedua sub sektor ini juga termasuk gas kota, namun di Lampung Utara Gas Kota belum ada. Untuk subsektor listrik mencakup seluruh pengoperasian mesin pembangkit listrik dari jenis apapun termasuk pengadaan tiangtiang pancang baik yang dilakukan oleh PLN maupun non PLN. Sub sektor air bersih meliputi usaha penjernihan, penampungan, dan pendistribusian air bersih untuk mensuplai masyarakat pemakai yang dikelola pemerintah daerah.

- Bangunan. Lingkup aktifitas sub sektor ini meliputi usaha pembangunan/ pembuatan, perluasan, pemasangan, perbaikan berat/ringan serta perombakan dari suatu bangunan atau konstruksi lainnya.

- Perdagangan, restoran, dan hotel terdiri dari; perdagangan eceran dan besar, rumah makan, perhotelan. Sub sektor ini meliputi perdagangan besar maupun eceran baik berupa barang baru, bekas, dan barang olahan yang dilakukan oleh pihak produsen, importir, lembaga, dan sebagainya.

- Pengangkutan; angkutan rel, jalan raya, laut, sungai, danau dan penyeberangan, udara, dan jasa penunjang angkutan.

- Komunikasi; pos dan tele-komunikasi, jasa penunjang komunikasi.

- Bank dan lembaga keuangan lainnya; bank, lembaga keuangan tanpa bank, jasa penunjang keuangan, sewa bangunan, dan jasa perusahaan.

- Jasa-jasa; sosial dan kemasyarakatan, hiburan dan rekreasi, perorangan dan rumah tangga.
Sektor-sektor yang dikembangkan Lampung Utara umumnya memberikan hasil yang cukup signifikan meski juga ada beberapa penurunan produksi, seperti data yang diperoleh dari setiap dinas instansi maupun dari Badan Pusat Statistik Kabupaten Lampung Utara. Namun demikian tidak semua sektor merupakan unggulan daerah ini, ada beberapa sektor yang termasuk kategori unggulan karena dominan dalam kondisi dan keadaan alam seperti pertanian serta pengangkutan, ada unggulan karena telah mengalami pengelolaan yang baik seperti sektor jasa rekreasi, hiburan, industri, komunikasi, perbankan, dan pertambangan. Adapun sektor lain bukan berarti tidak mempunyai kontribusi dalam pembangunan daerah, tetapi dalam pertumbuhan Kabupaten Lampung Utara sektor-sektor ini terus dikembangkan dan tidak menutup kemungkinan bahwa kelak sektor-sektor ini akan menjadi primadona Lampura.

Pembangunan adalah upaya bersama yang dilaksanakan pemerintah bersama rakyat dengan tujuan mencapai cita-cita nasional, yaitu terwujudnya masyarakat yang sejahtera, adil dan makmur. Agar pembangunan tersebut mencapai hasil maksimal, maka dibutuhkan suatu perencanaan pembangunan yang terarah, tepat sasaran, efektif dan efisien. Ini sesuai dengan pengertian Sikep pada motto Lampung Utara.

Kabupaten Lampung Utara yang telah mengalami tiga kali pemekaran wilayah ternyata membawa berkah tersendiri, karena dengan penciutan wilayah ini akan menjadikan pembangunan yang dilaksanakan lebih terarah, efektif dan efisien.

Hampir disepanjang masa Orde Baru, pertumbuhan ekonomi Lampung Utara menunjukkan angka positif sebagai pertanda adanya peningkatan perekonomian. Namun pada tahun 1998 
terdapat pengaruh eksternal dan internal yang menjadi penyebab turunnya perekonomian di Lampung Utara. Hal yang sama juga terjadi di daerah lain di Indonesia. Tahun ini dianggap sebagai tahun krisis karena menggapai seluruh aspek kehidupan seperti politik, sosial, budaya, dan perekonomian nasional.

Pengaruh eksternal terjadi akibat krisis ekonomi yang melanda negaranegara Asia membawa dampak yang buruk terhadap mata uang rupiah sehingga memperberat krisis ekonomi dalam negeri, besarnya utang luar negeri yang jatuh tempo, dan berkurangnya kepercayaan investor asing semakin melemahkan perekonomian nasional.

Pengaruh internal yang diakibatkan oleh ketidakstabilan politik dalam negeri pasca lengsernya Presiden Soeharto, terjadinya krisis kepercayaan terhadap pemerintah, dan tindakan spekulasi dari pelaku ekonomi semakin memperburuk perekonomian nasional.

Kedua kondisi di atas sangat berpengaruh terhadap pertumbuhan perekonomian di daerah. Beragam sub sektor perekonomian mengalami penurunan pertumbuhan yang signifikan. Data pertumbuhan ekonomi Kabupaten Lampung Utara dari tahun 1994-1998 memperlihatkan penurunan drastis seperti terlihat pada tabel berikut:

Tabel 3

Pertumbuhan Perekonomian Kabupaten Lampung Utara Persektor Tahun 1994$1998(\%)$

\begin{tabular}{|l|c|c|c|c|c|}
\hline Lapangan Usaha & 1994 & 1995 & 1996 & 1997 & 1998 \\
\hline - Pertanian & 5,51 & 5,17 & 5,34 & $-0,34$ & 1,25 \\
\hline - Penggalian & 38,76 & 28,29 & 22,31 & 8,50 & $-21,06$ \\
\hline $\begin{array}{l}\text { - Industri } \\
\text { Pengulahan }\end{array}$ & 8,92 & 16,09 & 4,82 & 12,94 & $-2,64$ \\
\hline $\begin{array}{l}\text { - Listrik dan Air } \\
\text { Bersih }\end{array}$ & 0,96 & 1,16 & 12,93 & 1,20 & 0,73 \\
\hline - Bangunan & 21,74 & 25,46 & 17,58 & 5,01 & $-30,05$ \\
\hline $\begin{array}{l}\text { - Perdagangan, } \\
\text { Hotel dan } \\
\text { Restaran }\end{array}$ & 6,06 & 7,95 & 5,39 & 1,76 & $-7,92$ \\
\hline
\end{tabular}

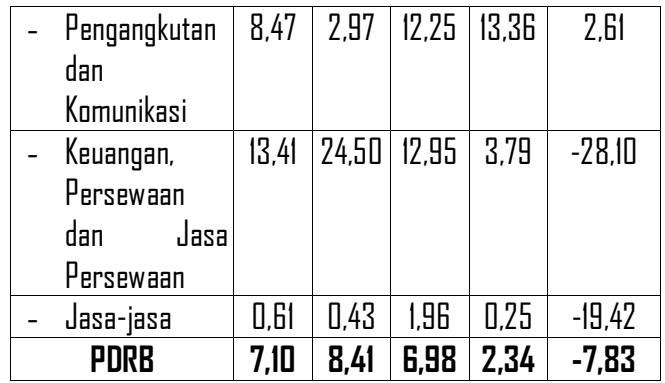

Sumber: PDRB Kabupaten Lampung Utara 1998:22

Pertumbuhan ekonomi Kabupaten Lampung Utara pada tahun 1994 tumbuh sebesar 7,10\%, tahun 1995 sebesar $8,41 \%$. Ini adalah puncak pertumbuhan ekonomi dalam rentang waktu empat tahun menjelang berakhirnya masa Orde Baru. Tahun 1996 mulai mengalami penurunan menjadi hanya $6,98 \%$, turun drastis pada tahun 1997 ke angka 2,34\%, dan puncak krisis pada tahun 1998 berada jauh di bawah 0 (nol) hanya mencapai $-7,83 \%$. Dari tabel 3.1 juga terlihat sub sektor yang dapat bertahan adalah pengangkutan dan komunikasi mencapai angka $2,61 \%$. Sub sektor yang paling terpuruk di penghujung kekuasaan Orde Baru adalah Bangunan -30,05\%.

Penurunan drastis terhadap PDRB ternyata tidak bersamaan dengan pendapatan perkapita masyarakat Lampung Utara. Justru pendapatan perkapita tersebut mengalami peningkatan yang cukup berarti. Indikator untuk menghitung nilai pendapatan perkapita ini adalah membagi nilai PDRB dengan jumlah penduduk dalam pertengahan tahun atau dikenal dengan PDRB Perkapita.

Perbandingannya adalah nilai regional perkapita yang diperoleh dengan terlebih dahulu menghilangkan pengaruh penyusutan dan pajak tidak langsung terhadap nilai PDRB dan membaginya dengan jumlah penduduk pertengah tahun. Hasil dari kedua pendapatan tersebut terlihat dalam tabel berikut: 
Tabel 4

PDRB Perkapita dan Pendapatan Regional Perkapita Kabupaten Lampung Utara tahun 1993-1998

\begin{tabular}{|c|c|c|c|c|}
\hline Tahun & $\begin{array}{c}\text { Jumlah } \\
\text { Penduduk } \\
\text { (Jiwa) }\end{array}$ & $\begin{array}{c}\text { Total } \\
\text { PDRB } \\
\text { (Juta } \\
\text { Rp.) }\end{array}$ & $\begin{array}{c}\text { PDRB } \\
\text { Perkapita } \\
\text { (Rp.) }\end{array}$ & $\begin{array}{c}\text { Pendapatan } \\
\text { Regional } \\
\text { Perkapita } \\
\text { (Rp.) }\end{array}$ \\
\hline 1993 & 503.757 & 403.809 & 801.595 & 730.250 \\
\hline 1994 & 520.567 & 493.542 & 948.085 & 871.017 \\
\hline 19955 & 563.920 & 574.560 & 1.070 .104 & 984.728 \\
\hline 1996 & 548.094 & 637.144 & 1.162 .472 & 1.069 .143 \\
\hline 1997 & 559.714 & 690.720 & 1.234 .059 & 1.133 .417 \\
\hline 1998 & 571.580 & 819.690 & 1.434 .077 & 1.318 .798 \\
\hline
\end{tabular}

Sumber: PDRB Kabupaten Lampung Utara 1998:27.

Pertumbuhan PDRB perkapita penduduk Lampung Utara terus membaik bahkan ketika krisis nasional disegala bidang sedang melanda. Kenaikan ini juga berdampak baik pada pertumbuhan PDRB kabupaten.

Babakan baru dalam sejarah Indonesia justru dimulai pada tahun berikutnya. Euforia "kemenangan" menjalar sangat cepat, sedangkan kondisi bangsa tidak juga membaik. Tahun 1999 menjadi awal masa Reformasi. Secara umum pertumbuhan ekonomi mulai membaik. Hal ini ditunjukkan dengan terjadinya peningkatan sebesar $2,45 \%$ PDRB hampir di semua sub sektor, kecuali pada sub sektor penggalian, industri, bangunan, dan keuangan, tampaknya masih terpukul akibat krisis tahun 1998.

\section{Penutup}

Kabupaten Lampung Utara yang mengalami tiga kali pemekaran wilayah ternyata mampu bertahan menghadapi krisis ekonomi. Kiprah pemerintah daerah yang mengayomi rakyatnya dan menjadi pemandu dalam gerak pembangunan, menghasilkan pertumbuhan eko- nomi yang demikian baik. Sehingga salah satu dari sepuluh daerah tingkat II di Provinsi Lampung ini terus bergerak maju dan tidak stagnan. Rupanya motto Gertak Saburai Sikep yang merupakan penyederhanaan dari Gerbang Sakai Sambaian Lampura Sikep, pemerintah Kabupaten Lampung Utara menggerakkan masyarakat secara gotong royong untuk pembangunan pedesaan telah menampakkan hasil.

Tingkat keberhasilan pembangunan di Kabupaten Lampung Utara dievaluasi pada tiap akhir tahun dengan tujuan penyempurnaan program dan pelaksanaan pembangunan berdasarkan kemampuan dan potensi yang dimiliki. Beberapa program utama yang menjadi sorotan adalah peningkatan kemampuan sdm di lingkungan aparatur pemerintah termasuk di dalamnya penambahan jumlah pegawai dengan kualifikasi yang lebih spesifik (ahli di bidang masingmasing) dan pelatihan-pelatihan yang dilaksanakan guna menunjang SDM tersebut. Program lainnya yang turut menjadi perhatian adalah perbaikan dan penambahan jalur perhubungan darat yang menjadi urat nadi bergeraknya perekonomian timbal balik antara daerah penghasil dengan pasar. Jaringan komunikasi serta jaringan listrik yang merata turut menjadi perhatian sebab kedua infrastruktur ini sangat dibutuhkan dalam rangka pengembangan pembangunan tersebut.

\section{DAFTAR PUSTAKA}

\section{Buku}

Badan Pusat Statistik Kab. Lampung Utara. 1999.

Gottschalk, Louis. 1986.

Understanding History: A Primer of Historical Method, Mengerti 
Sejarah, terj. Nugroho Notosusanto, Cet. V. Jakarta: UI-Press.

Kantor Sensus dan Statistik Kab. Lampung Utara.1975. Lampung Utara Dalam Angka 1974.

Kantor Statistik Kab. Lampung Utara. 1981. Lampung Utara dalam Angka 1980.

Kantor Statistik Kab. Lampung Utara. 1991. Lampung Utara dalam Angka 1990-1991.

Kuntowijoyo. 1999.

Pengantar Ilmu Sejarah .Cet. III. Yogyakarta: Yayasan Bentang Budaya.

Lampung Utara dalam Angka 1998. Badan Pusat Statistik Kab. Lampung Utara. 1999.
Leirissa, R.Z. et.al. 1996.

Sejarah Perekonomian Indonesia. Jakarta: Depdikbud.

Produk Domestik Regional Bruto Kabupaten Lampung Utara 1993-1998.

Suriadiningrat, Bayu. 1981.

Sejarah Pemerintahan di Indonesia. Babak Hindia Belanda dan Jepang. Jakarta: Dewaruci Press.

30 Tahun Indonesia Merdeka 1945-1949. Cet. Keempat. Jakarta: PT. Tira Pusaka, 1981.

Wasistiono, M.S., Sadu. atal. 2002.

Pengelolaan Sektor Perhubungan dalam Rangka Penyelenggaraan Otonomi Daerah. Bandung: Fokusmedia.

\section{Sumber Elektronik}

www.perdaonline.org www.petadigital.com www.lampungkab.go.id supriliwa.wordpress.com 